\title{
A comparative study of four indexes based on zooplankton as trophic state indicators in reservoirs
}

\author{
Daniel Montagud ${ }^{1,}$, , Juan M. Soria ${ }^{1}$, Xavier Soria-Perpiñà $^{2}$, Teresa Alfonso ${ }^{1}$ and Eduardo \\ Vicente $^{1}$ \\ ${ }^{1}$ Cavanilles Institute of Biodiversity and Evolutionary Biology (ICBIBE). University of Valencia, 46980-Pater- \\ na, Spain. \\ 2 Image Processing Laboratory. University of Valencia, 46980-Paterna, Spain. \\ * Corresponding author: damonta@alumni.uv.es
}

Received: $15 / 02 / 18 \quad$ Accepted: 25/06/18

\begin{abstract}
A comparative study of four indices based on zooplankton as trophic state indicators in reservoirs

This study aims to examine four recently conducted trophic state indices that are based on the density of zooplankton and designed for estimating the trophic state of inland waters. These indices include two with formulations based on quotients or ratios, the Rcla and the Rzoo-chla, which were proposed and validated in the European project ECOFRAME (Moss et al., 2003), and two with formulations based on the incorporation of a statistical tool comprising canonical correspondences analysis (CCA), the Wetland Zooplankton Index proposed in 2002 by researchers from McMaster University of Ontario (Lougheed \& Chow-Fraser, 2002) and the Zooplankton Reservoir Trophic Index, an index recently designed by the Ebro Basin Authority and on which this manuscript is the first article. These indices were studied and applied in 53 heterogeneous reservoirs of the Ebro Basin. In addition, all were subsequently validated by Carlson's Trophic State Index based on the amount of chlorophyll $a$ (Carlson, 1977), with significant differences found between them.
\end{abstract}

Key words: bioindicators, trophic state, Ebro Basin, zooplankton, canonical correspondence analysis, zooplankton reservoir trophic state index

\section{RESUMEN}

Estudio comparativo de cuatro índices basados en el zooplancton como indicadores de estado trófico en embalses

El presente estudio pretende estudiar cuatro índices de estado trófico realizados recientemente, basados en la densidad del zooplancton y diseñados para la estimación del estado trófico de las aguas continentales. Estos índices fueron dos cuya formulación se basa en cocientes o ratios, el Rcla y el Rzoo-chla que se propusieron y validaron en el proyecto europeo ECOFRAME (Moss et al., 2003), y dos cuya formulación se basa en la incorporación de una análisis estadísticos de correspondencias canónicas (CCA), el Wetland Zooplankton Index propuesto en el año 2002 por investigadores de la Universidad McMaster de Ontario (Lougheed \& Chow-Fraser, 2002) y el Zooplankton Reservoir Trophic Index, indice diseñado recientemente por la Confederación Hidrográfica del Ebro y del cual el presente manuscrito representa su primer artículo científico al respecto. Dichos índices fueron estudiados y aplicados en 53 embalses heterogéneos de la Confederación Hidrográfica del Ebro. Además, todos ellos fueron validados a posteriori mediante el Trophic State Index de Carlson basado en la cantidad de clorofila a (Carlson, 1977), observándose diferencias significativas entre ellos.

Palabras clave: bioindicadores, estado trófico, lagos de la cuenca del Ebro, zooplancton, análisis de correspondencias canónicas, zooplankton reservoir trophic state index 


\section{INTRODUCTION}

Numerous studies conducted since the mid-1980s demonstrate the relationship between zooplanktonic communities and the trophic states of inland water bodies (e.g., Bays et al., 1983; Gulati, 1983; Blancher, 1984). This premise led to the study of zooplankton as a possible bioindicator of the ecological potential of different inland water bodies (e.g., Burns et al., 1999; Caramujo \& Boavida, 2000; Lougheed \& Chow-Fraser, 2002).

Four indices based on zooplankton were studied in this paper, two of which do not present a statistical tool and two with a multivariate statistical component. The former indices are the ratio of big cladocers to total cladocers (Rcla) and the ratio of biomass zooplankton to the chlorophyll a concentration (Rzoo-chla), which are based on ratios or quotients. The latter are the Wetland Zooplankton Index (WZI) and the Zooplankton Reservoir Trophic Index (ZRTI), which include an analysis of canonical correlations (CCA) between environmental, physical and chemical variables and zooplankton taxa to observe the relationships between them and obtain coefficients or multiplication factors for each of the zooplankton species considered.

The Rcla and Rzoo-chla indices were proposed and validated in the European ECOFRAME project. They were studied in various shallow lakes in different European countries (Finland, Sweden, Estonia, Denmark, Germany, Poland, Ireland, the UK, the Netherlands and Spain) (Moss et al., 2003).

The WZI index was proposed in 2002 by researchers at McMaster University in Ontario to determine the ecological potential of the Great Lakes in the northern United States and southern Canada (Lougheed \& Chow-Fraser, 2002).

Finally, the ZRTI was proposed and produced by the Ebro River Basin Authority to determine the ecological potential of its reservoirs by considering zooplankton and other variables as quality indicators.

The ZRTI index has already been used in the Ebro Basin Authority's annual reports monitor-

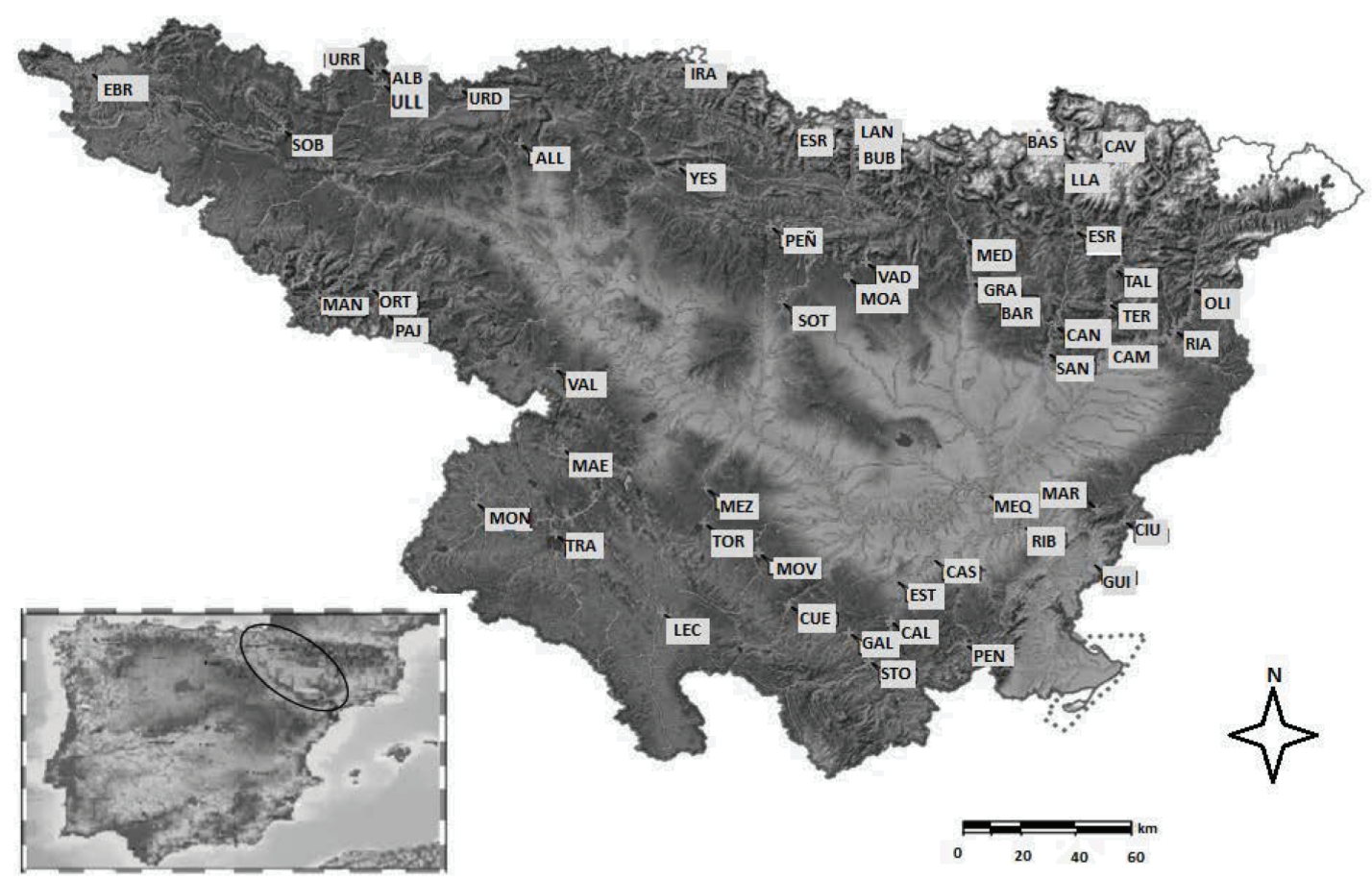

Figure 1. Location map of reservoirs in Ebro basin. Mapa de la situación de los embalses de la Cuenca del Ebro. 
ing the water quality of its reservoirs (CHE, 2009), but no study has been conducted to review its suitability and operation for quality assesment, except for its initial presentation (Mellado et al., 2010).

This study was motivated by the need to formulate and implement a biological index for determining the ecological potential of reservoirs, since no such index has yet been formulated specifically for reservoirs, and, therefore, the need for such an index is urgent for compliance with the European Water Framework Directive (EC 2000).

This study validates the new ZRTI index, as it demonstrates its correct functioning in the reservoirs studied, as well as in comparisons with other indices, the functionalities of which are already consolidated.

Therefore, this study aims to analyze various indices of diverse origin, all of them based on zooplankton, to observe differences among them and validate them by means of the Trophic State Index (Carlson's TSI), an index based on the concentration of chlorophyll $a$ (Carlson, 1977) in several water samples. Which index is most efficient in diagnosing environmental quality? And is it possible to use indices produced in other regions in our area of study? This paper intends to investigate these questions.

\section{METHODOLOGY}

Data have been collected from samples of environmental variables and zooplankton density in 53 different reservoirs, all of which have heterogeneous characteristics and belong to the territorial demarcation of the Ebro Basin. Field sampling took place during the summer periods from 2014 to 2016 to determine the water quality of these reservoirs using the official methodology established for this purpose. These reservoirs present heterogeneous characteristics, since the Ebro River Basin has a wide territorial extension that covers a region that ranges from the Cantabrian high mountains to the Pyrenees and the Iberic Mountains to the Catalan coastal zone, presenting climatic and lithological differentiations that attributes different characteristics to each reservoir. The reservoirs, with their abbrevi- ations, are geolocated in Figure 1. The abbreviations, the year of sampling and the various heterogeneous properties of each site can be found in Table S1 (see supplementary information at http://www.limnetica.net/en/limnetica).

In accordance with the official methodology (Vicente et al., 2005), a single sampling station was established in the deepest part of each reservoir, at a distance of between 100 and 300 meters from the dam.

\section{Physical and chemical variables}

The depth of the photic zone was determined by measuring light penetration using a PAR quantometer. In addition, in situ water transparency was determined using the Secchi disc technique. The temperature, dissolved oxygen, conductivity and $\mathrm{pH}$ of the water were measured in situ continuously along the vertical profile approximately every 5 $\mathrm{cm}$ by means of the multiparametric probe Sea-Bird 19 plus V2 (SBE19). An integrated water sample was collected from the photic zone using the $25 \mathrm{~mm}$ diameter ballasted tube technique, or, in accordance with the official methodology, at least a $6 \mathrm{~m}$ deep column if the depth of the photic zone was lower than $6 \mathrm{~m}$ (Vicente et al., 2005). The aliquots corresponding to the analyses were separated into different bottles.

The analytical methodology described in APHA 2540D (APHA, 1998) was used to determine total suspended solids and total volatile solids. The indophenol method was used in the determination of ammonium (Verdow et al., 1978). Total nitrogen was obtained using the analytical methodology described in APHA method 4500-N C (APHA, 1998). For the determination of total phosphorus, the methodology described in APHA method 4500-P B/APHA 4500-P C (APHA, 1998) was used, with a limit of detection and quantification of $0.2 \mu \mathrm{g} P / \mathrm{L}$, and the determination of chlorophyll $a$ was obtained following the analytical methodology described in method APHA $1200 \mathrm{H}$ (APHA, 1998). For the determination of dissolved carbon, the samples were manipulated and analyzed according to the protocols described in Soria (2017), using the non-purgeable organic carbon method in a Shimadzu TOC-VCSH/CSN analyzer. 


\section{Biological variables}

The biological variable considered in this study was zooplankton density expressed in individuals/litre. The guides used for the taxonomic identification of zooplankton were Stella (1984), Segers (1995), Nogrady et al. (1995), Benzie (2002) and Nogrady \& Segers (2002). The depth of collection of the zooplankton sample was determined by trying to incorporate the zone of the beginning of oxygen decline, which generally coincides with the end of the photic zone. This area is the richest in this type of fauna during the day (Miracle et al., 1983). Using a Ruttner vertical hydrographic bottle with a capacity of $2.6 \mathrm{~L}$, two samples of $2.6 \mathrm{~L}$ each were collected and filtered by means of $20 \mu \mathrm{m}$ pore nytal mesh, which was preserved in formaldehyde at a final concentration of 4-5\%. For the capture of the qualitative zooplankton present in the medium, a vertical trawl was carried out in all reservoirs with a $50 \mu \mathrm{m}$ pore zooplankton net, which was also preserved in formalin and used for taxonomic studies. For the determination of the zooplanktonic community a Sedgewick Rafter-type counting chamber was used and implemented using a stereoscopic inverted microscope to count the crustaceans, while an optical microscope was normally required for their identification, as well as for the counting-identification of rotifers, for which an inverted microscope was also used. A dye (Rose Bengal) was used to facilitate counting and identification when necessary.

\section{Calculation of the indices}

As indicated above, four indices were used, two based on ratios, the Rcla and the Rzoo-chla, and two based on the integration of zooplanktonic species in a statistical analysis of CCA, the WZI and the ZRTI. In the CCAs performed for the calculation of WZI and ZRTI, a Montercalo permutation test was also performed with $\mathrm{N}=999$.

\section{Rcla and Rzoo-chla indices}

The Rcla and Rzoo-chla indices were formulated in the ECOFRAME project for the study of the ecological quality of shallow lakes (Moss et al., 2003).
The Rcla index is the result of the ratio between the number of big cladocers to the total number of cladocers (in this work, species of the genera Diaphanosoma and Moina, as well as the species Leydigia leydigii, Holopedium gibberum and Simocephalus vetulus, all of which are between $0.2-5.0 \mathrm{~mm}$ long, were considered big cladocers), and the Rzoo-chla index is the result of the ratio between the total zooplankton biomass and volume in $\mathrm{mg} / \mathrm{L}$. The biomass was estimated from biovolume calculations, assuming a specific gravity of $1 \mathrm{~mm}^{3}$ (Wetzel et al., 2000), and the phytoplankton were expressed as chlorophyll $a$ concentration.

\section{WZI index}

Abbreviated from Wetland Zooplankton Index (Lougheed \& Chow-Fraser, 2002). This index was developed in the USA for assessing the quality of aquatic ecosystems of different types (palustre, lake, river, etc.) using zooplankton communities. Eight physical and chemical variables are used in its CCA: temperature, dissolved oxygen, conductivity, $\mathrm{pH}$, total suspended solids, chlorophyll $a$, phosphorus and total nitrogen.

The index uses tolerance ( $T i$ ) and optimal (Ui) values for different genera and species of zooplankton (rotifers, copepods and cladocers). These values have been obtained from the results of the first axis in the CCA according to the authors' methodology.

The mathematical expression of the index is:

$$
\mathrm{WZI}=\frac{\sum_{i=1}^{n} Y_{i} T_{i} U_{i}}{\sum_{i=1}^{n} Y_{i} T_{i}}
$$

Where $Y i$ is the abundance (ind/L) of species $i, T i$ is its tolerance (values 1-3) and $U i$ is its optimum (values 1-5). The index therefore varies from 1 (poor indicator) to 5 (maximum quality indicator).

The optimum $U$, or center of distribution, and the tolerance $T$, or range of distribution, values were determined for each taxon based on a CCA 
using these collapsed taxonomic groupings. The location of a taxon on CCA axis 1 is represented by the center of distribution along the primary synthetic axis formed by several key environmental variables (Ter Braak et al., 1995). In general, taxa tolerant of degraded conditions $(U=1-2)$ had broader tolerance $(T=1)$, while those less tolerant $(U=4-5)$ of degraded conditions often had a narrower tolerance $(T=3)$. The $U$ and $T$ values for each species obtained for each zooplanktonic species can be found in Table S2 (see supplementary information at http://www. limnetica.net/en/limnetica).

\section{ZRTI index}

As mentioned above, one of the novel aspects of this publication is the incorporation of the ZRTI, an index used to obtain the ecological potential of the reservoirs of the Ebro River Basin. As in the WZI, eight physical and chemical variables were used in the CCA: Secchi's disk values, photic zone depth, total volatile solids, total ammonium, total dissolved carbon, chlorophyll $a$, phosphorus and total nitrogen. For zooplankton, the density values of all taxa were identified.

For the calculation of the ZRTI, each taxon was assigned a tolerance eutrophy value $t i$ ranging from 1 (minimum tolerance) to 15 (maximum tolerance), calculated from its relative position in the trophic state gradient as defined by the first axis of ordering and according to the procedure established here:
-The lowest weight obtained in the CCA was divided into 7.5 parts, and the result of the division is the threshold value for each category (from 1 to 7 ).

-The highest weight obtained in the CCA was divided into 7.5 parts, and the result of the division is the threshold value for each category (from 9 to 15). Central category around 0 value is the value 8 .

The index is the weighted sum (with the relative density of each species $d i$ as a weighting factor) of the tolerance values of the species present in each reservoir:

$$
\mathrm{ZRTI}=\Sigma \text { di ti }
$$

Where $d i$ is the relative density and $t i$ is the tolerance value of species $i$.

The ZRTI index ranges from 1 to 15, with ecological classes (called Ecological Potentials) being calculated by equitably dividing this range into five quality classes as shown in Table 1.

The ti values obtained for each zooplanktonic species can be found in Table S2.

\section{Index validation}

Carlson's TSI (Carlson, 1977) based on the concentration of chlorophyll $a$, an index with consolidated functionality, was used to validate the indices, and a conventional linear regression was subsequently carried out using the Excel software package.

Table 1. Ecological potential value classes for the different índices. Porcentaje de representación. Clases de valores del potencial ecológico para los diferentes índices.

\begin{tabular}{lrrrrr}
\hline Ecological potential classes & Optimal & Good & Moderate & Deficient & Bad \\
\hline Rcla Range & $>0.5$ & $0.3-0.5$ & $0.1-0.3$ & $0.05-0.1$ & $<0.05$ \\
Rzoo-chla Range & $>70$ & $50-70$ & $20-50$ & $10-20$ & $<10$ \\
WZI Range & $>4.2$ & $3.4-4.2$ & $2.6-3.4$ & $1.8-2.6$ & $<1.8$ \\
ZRTI Range & $<3.8$ & $3.8-6.6$ & $6.6-9.4$ & $9.4-12.2$ & $>12.2$ \\
Carlson's TSI Range & $<20$ & $20-40$ & $40-60$ & $60-80$ & $>80$ \\
\hline
\end{tabular}




\section{Statistical processing}

The physical and chemical variables used to calculate the indices were temperature, dissolved oxygen, water conductivity, $\mathrm{pH}$, total suspended solids, total nitrogen and phosphorus, chlorophyll $a$, water transparency, depth of the photic zone, total volatile solids, ammonium and total dissolved organic carbon. The multivariate statistical analysis of CCAs and the Montecarlo permutation test for the WZI and ZRTI indices was performed using the free downloadable software package PAST version 3.18 (Hammer $e t$ al., 2001). All data used have been transformed to a logarithmic neperian scale for standardization, except $\mathrm{pH}$.

\section{RESULTS}

\section{Physical and chemical variables}

The mean, maximum and minimum values of each physical and chemical variable studied are given in Table 2. In general, the values that correspond to indicators of higher quality are found in the reservoirs of the Pyrenean area (Cavallers, Llauset \& Canelles), while the values corresponding to low-quality indicators are found in small, medium or low reservoirs, as is the case of Lechago, Terradets, or located in poor quality rivers like Oliana, Cueva Foradada and Moneva. Most reservoirs present values indicating intermediate qualities of the variables used.

With respect to zooplankton, 75 different taxa were identified across all the reservoirs. The taxonomic group with the most species found was that of rotifers with 48 different species, followed by the taxonomic group of cladocers with 16 different species, and the taxonomic group with the fewest species was that of the copepods with 11 different species.

If we look at the density of total zooplankton, the reservoir with the highest value was Moneva with 5911 individuals/L, while the reservoir with the lowest value of zooplankton density was Sopeira reservoir with 8 individuals/L.

But if we focus on the density of the large cladocerans (see Methodology section), a variable necessary for the calculation of the Rcla
Table 2. Mean, maximum and minimum of physical and chemical variables. Promedio, máximo y mínimo de las variables fisicoquímicas.

\begin{tabular}{lrrr}
\hline Variables & Average & Maximum & Minimum \\
\hline Temperature $\left({ }^{\circ} \mathrm{C}\right)$ & 18.61 & 27.50 & 10.50 \\
Oxygen $(\mathrm{mg} / \mathrm{L})$ & 8.21 & 10.10 & 4.75 \\
Conductivity $(\mu \mathrm{S} / \mathrm{cm})$ & 371.96 & 1372.00 & 12.29 \\
pH & 8.12 & 8.64 & 6.98 \\
Solids $(\mathrm{mg} / \mathrm{L})$ & 3.27 & 16.79 & 0.07 \\
N total $(\mu \mathrm{M})$ & 51.74 & 306.78 & 8.48 \\
P total $(\mu \mathrm{M})$ & 0.36 & 2.61 & 0.03 \\
Chlorophyll $a(\mu \mathrm{g} / \mathrm{L})$ & 3.24 & 21.27 & 0.54 \\
Secchi disk depth $(\mathrm{m})$ & 4.18 & 17.20 & 0.75 \\
Photic zone depth $(\mathrm{m})$ & 11.84 & 43.00 & 3.10 \\
Volatile solids $(\mathrm{mg} / \mathrm{L})$ & 0.97 & 4.60 & 0.05 \\
Ammonium $(\mu \mathrm{M})$ & 1.47 & 6.83 & 0.09 \\
Dissolved carbon $(\mathrm{mg} / \mathrm{L})$ & 1.74 & 3.57 & 0.37 \\
\hline
\end{tabular}

index, the highest value corresponds to the Rialb reservoir with 55 individuals/L, while the reservoir with the lowest density of large cladocerans is Llauset, in which no individual was found.

\section{Analysis of Canonical Correspondences}

In the CCA with the same physical and chemical variables corresponding to the WZI index, 31.66 $\%$ of the cumulative variance on axis 1 (the only axis of the analysis of interest to us) was obtained with a $p$ value of 0.001 in the Monte Carlo permutation test. It was observed that those variables associated with eutrophication and poor water quality (temperature, conductivity, total solids, chlorophyll $a$, nitrogen and total phosphorus) had a negative weight on the first axis, while dissolved oxygen, associated with higher water quality (Bengraïne \& Marhaba, 2003), had a positive weight. The $\mathrm{pH}$ variable was at the midpoint, value 0 . The variable with the most negative weight was conductivity, while dissolved oxygen had the most positive weight on the first axis.

In this same CCA, it was observed that those species belonging to the Cladocera taxonomic group had positive values, while the species belonging to the Rotifera taxonomic group were located more to the negative side of the axis. The species with the most positive statistical weight 
Table 3. Result of the indices in the reservoirs. Grey scale for quality as in Table 1. Resultado de los indices en los embalses. Escala de grises para la calidad como en la tabla 1.

\begin{tabular}{|c|c|c|c|c|c|}
\hline Reservoir & Rcla Value & Rzoo-Chl $a$ Value & WZI Value & ZRTI Value & Carlson's TSI \\
\hline Albiña & 1.00 & 97.37 & 3 & 7 & 43 \\
\hline Alloz & 0.93 & 55.60 & 3 & 8 & 41 \\
\hline Barasona & 0.00 & 11.44 & 3 & 7 & 45 \\
\hline Baserca & 1.00 & 28.88 & 3 & 6 & 41 \\
\hline Búbal & 0.96 & 66.56 & 3 & 7 & 39 \\
\hline Calanda & 0.98 & 80.08 & 3 & 9 & 37 \\
\hline Camarasa & 0.10 & 59.99 & 3 & 8 & 42 \\
\hline Canelles & 0.84 & 30.79 & 3 & 7 & 44 \\
\hline Caspe & 0.93 & 71.64 & 3 & 10 & 40 \\
\hline Cavallers & 1.00 & 118.29 & 3 & 5 & 37 \\
\hline Ciurana & 0.51 & 44.19 & 3 & 8 & 38 \\
\hline Cueva Foradada & 1.00 & 108.19 & 3 & 9 & 44 \\
\hline Ebro & 1.00 & 27.53 & 3 & 8 & 42 \\
\hline Escales & 0.91 & 30.95 & 3 & 7 & 43 \\
\hline Escarra & 0.90 & 64.88 & 3 & 6 & 38 \\
\hline Estanca & 1.00 & 32.33 & 3 & 9 & 45 \\
\hline Gallipuen & 0.09 & 401.62 & 3 & 9 & 40 \\
\hline Grado & 0.00 & 17.71 & 3 & 8 & 36 \\
\hline Guiamets & 0.23 & 12.07 & 3 & 8 & 48 \\
\hline Irabia & 0.70 & 19.93 & 3 & 8 & 44 \\
\hline Lanuza & 0.99 & 142.66 & 3 & 7 & 37 \\
\hline Lechago & 1.00 & 81.40 & 4 & 11 & 45 \\
\hline Llauset & No cladocers found & 1.13 & 3 & 5 & 35 \\
\hline Maidevera & 0.11 & 76.64 & 3 & 8 & 51 \\
\hline Mansilla & 0.84 & 9.67 & 3 & 7 & 43 \\
\hline Margalef & 1.00 & 30.22 & 3 & 8 & 46 \\
\hline Mediano & 0.19 & 35.38 & 3 & 7 & 41 \\
\hline Mequinenza & 0.45 & 92.86 & 4 & 9 & 46 \\
\hline Mezalocha & 0.33 & 24.10 & 3 & 8 & 48 \\
\hline Montearagón & 0.19 & 11.50 & 3 & 7 & 43 \\
\hline Monteaguda de las Vicarias & 0.98 & 71.02 & 4 & 11 & 44 \\
\hline Moneva & 0.94 & 77.34 & 4 & 11 & 47 \\
\hline Oliana & 0.65 & 26.22 & 3 & 8 & 51 \\
\hline Ortigosa & 1.00 & 9.87 & 3 & 8 & 39 \\
\hline Pajares & 0.99 & 27.56 & 3 & 8 & 42 \\
\hline Pena & 0.98 & 85.55 & 3 & 7 & 36 \\
\hline La Peña & 0.00 & 7.56 & 3 & 8 & 47 \\
\hline Rialb & 0.59 & 98.02 & 3 & 8 & 45 \\
\hline Ribarroja & 0.48 & 57.18 & 3 & 9 & 46 \\
\hline Santa Ana & 0.52 & 12.82 & 3 & 7 & 41 \\
\hline Sobron & 0.62 & 17.92 & 3 & 9 & 55 \\
\hline La Sotonera & 0.05 & 19.77 & 3 & 9 & 45 \\
\hline Santolea & 0.97 & 46.42 & 3 & 8 & 38 \\
\hline Talarn & 1.00 & 17.41 & 3 & 7 & 45 \\
\hline Terradets & 1.00 & 1.56 & 3 & 7 & 41 \\
\hline Las Torcas & 0.58 & 39.20 & 3 & 8 & 43 \\
\hline La Tranquera & 0.10 & 58.66 & 3 & 9 & 50 \\
\hline Ullivarri & 0.04 & 124.17 & 3 & 9 & 42 \\
\hline Urdalur & 0.77 & 12.06 & 3 & 8 & 40 \\
\hline Urrúnaga & 0.04 & 6.63 & 3 & 7 & 49 \\
\hline Vadiello & 0.34 & 12.25 & 3 & 7 & 39 \\
\hline El Val & 0.64 & 15.07 & 3 & 8 & 61 \\
\hline Yesa & 0.80 & 5.25 & 3 & 7 & 42 \\
\hline
\end{tabular}


on the first axis was Holopedium gibberum, while the species with the most negative value was Hexarthra oxyuris.

In the CCA with the physical and chemical variables established by the ZRTI methodology, $32.0 \%$ of the cumulative variance on axis 1 was obtained with a $p$ value of 0.001 in the Monte Carlo permutation test. It was observed that, contrary to the previous case, the physical and chemical variables associated with a higher water quality were located in the negative part of the axis (transparency and depth of the photic zone), while the variables associated with poor quality were located at the most positive part of the axis (total volatile solids, ammonium). The variable with the most negative value in the first axis was the depth of the photic zone, and the total carbon dissolved was the variable with the most positive value on the first axis.

Regarding zooplankton, in the CCA of the ZRTI, it was observed that the species belonging to the Cladocera taxonomic group had more negative values, while the species belonging to the Rotifera taxonomic group were located more to the positive part of the axis. The species with the most negative statistical weight on the first axis was Holopedium gibberum, while the species with the most positive value was Hexarthra oxyuris, the same findings as those of the statistical analysis for WZI, which used different environmental variables.

\section{Index results}

The results obtained in the application of the various indices in all 53 reservoirs analyzed can be seen in Table 3.

According to the Rcla index, $67 \%$ of the total reservoirs are ultraoligotrophic, $8 \%$ oligotrophic, $12 \%$ mesostrophic, $4 \%$ eutrophic and $10 \%$ hypertrophic. Without focusing on the Rzoo-chla index, $28 \%$ are ultraoligotrophic, $11 \%$ are oligotrophic, $30 \%$ are mesotrophic, $21 \%$ eutrophic and $9 \%$ hypertrophic.

The WZI, ZRTI and Carlson's TSI indices do not establish any reservoir as either ultraoligotrophic or hypertrophic. More specifically, according to WZI, $8 \%$ of the reservoirs are oligotrophic and $92 \%$ are mesostrophic. The
ZRTI also states that $8 \%$ of the total number of reservoirs are oligotrophic but that $85 \%$ are mesostrophic and $8 \%$ eutrophic. Finally, the Carlson's TSI index states that $23 \%$ of reservoirs are oligotrophic, while $68 \%$ are mesostrophic and $9 \%$ eutrophic.

\section{Validations}

As stated in the previous section, all indices were related and compared with Carlson's TSI. The statistical values obtained in the various regressions can be seen in Table 4 .

The least significant values were those obtained in the two indices based on quotients or ratios, the Rcla and the Rzoo-chla, with the Rzoo-chla being more insignificant. Among the indices based on CCA statistics, ZRTI was the most significant.

In addition, for greater reliability of the conclusions, an additional validation of the ZRTI was carried out using only data from 2017 , as these data are the most recently sampled. The critical value in Pearson's $r$ for this validation turned out to be less than 0.001 (Dunnett, 1964), as shown in Table 4.

\section{DISCUSSION}

This study demonstrated the relationship between the trophic status of water bodies and the zooplankton community present, indicating that these organisms are suitable for the development of biological indices for the determination of ecological potential, as stated by several authors (eg., Ochocka et al., 2016; Gilbert et al., 2017).

Table 4. Result of index validations with Carlson's TSI. $\mathrm{N}=53$ for 2014-16 data; $\mathrm{N}=40$ for 2017 data. Resultado de las validaciones de los indices con el TSI de Carlson. $N=53$ en datos del 2014-2016; $N=40$ en datos del 2017.

\begin{tabular}{lcc}
\hline Index & R Coeficient values & R Pearson critical values \\
\hline RCLA & 0.277 & 0.025 \\
Rzoo-Chl $a$ & 0.180 & $>0.05$ NO SIGNIFICANT \\
WZI & 0.296 & 0.025 \\
ZRTI & 0.332 & 0.01 \\
ZRTI 2017 & 0.504 & $<0.001$ \\
\hline
\end{tabular}


This study also found differences between the various indices studied. We observe many discrepancies in the allocations of trophic states depending on which indices are considered. While the results obtained in the statistical indices are related to the trophic state established by Carlson's TSI, a reference index, the indices based on quotients or ratios show no relation to the result obtained from Carlson's TSI. For example, the Yesa reservoir is classified as a mesotrophic reservoir by the WZI and ZRTI statistical indices and Carlson's TSI, while the Rcla index classifies it as ultraoligotrophic and the Rzoo-chla as hypertrophic.

It is observed that the ecological classification of reservoirs according to the indices based on CCA statistics is related to the results obtained in Carlson's TSI, while the classification of reservoirs according to the results obtained in the application of the indices based on quotients or ratios, Rcla and Rzoo-chla, have no apparent relationship either between them or with the other indices, including Carlson's TSI.

As for the validation of the different indices with respect to Carlson's TSI, we observed that the indices presenting statistics in their mathematical algorithm are statistically more correlated than the indices based on ratios, among which the Rzoo-chla was found to be not significant.

Although a more specific study of why these discrepancies exist and a reformulation of the indices based on quotients or ratios to enhance performance in this type of aquatic mass is necessary, one possible reason for their poor performance is that they were designed in the ECOFRAME project (Moss et al., 2003) for shallow lagoons in several European countries; therefore, applying them to highly modified waters (reservoirs) in various regions gave an unsatisfactory result. Regardless, as already mentioned, among the indices that were studied in the present work, the one that adjusted worst to the trophic state of the reservoir was the Rzoo-chla, an index based on the ratio between the total existing zooplankton and the phytoplanktonic biomass expressed by the amount of chlorophyll $a$. One reason for its functional weakness could lie precisely in its formulation, since it assumes the same properties of all zooplankton species, even though many studies disprove this, and it could result in co-cataloguing species of zooplankton bioindicators of higher water quality that in most cases require favorable characteristics for their development with zooplankton species that have the widest trophic spectrum (Gannon et al., 1978).

The statistical part of this study reflected the existence of zooplankton species indicating good ecological potential. For the CCAs carried out for the calculations of both WZI and ZRTI, the species belonging to the Cladocera taxonomic group were associated with a good ecological quality, namely the species Cyclops abyssorum and Holopedium gibberum, the latter being the species associated with better conditions of ecological quality in both cases.

Conversely, in both cases, species belonging to the taxonomic group of the Rotifera were in the parts of the axis related to bad ecological status; specifically, the species Hexarthra oxyuris, Hexathra mira, Keratella tropica and Keratella quadrata indicated low ecological quality.

These conclusions are consistent with most studies related to zooplankton as an ecological indicator (e.g., Pinto-Coelho et al., 2005; Ejsmont-Karabin, 2012; Haberman et al., 2014; Azevedo et al., 2015), which find more individuals of the Rotifera taxonomic group in low quality areas and of the Cladocera taxonomic group in areas of higher ecological quality. These conclusions also agree with several studies of the populations of zooplankton in eutrophic lagoons in Spain, including Lavajo de Abajo de Sinarcas (Sahuquillo \& Miracle, 2010) and La Albufera (Vicente \& Miracle, 1992), that found that the most abundant species are of the taxonomic group of the Rotifera, specifically the species Hexathra mira, Keratella quadrata and Keratella tropica. Along the same lines, several studies carried out in reservoirs of the Júcar river detected the presence of individuals from the Rotifera taxonomic group in reservoirs of low water quality (García-Chicote et al., 2017).

In the same way, this study was able to validate the correct functionality of the new trophic status index based on the ZRTI. This index has given the best statistical results among those studied here, with an r-Pearson $p$-value (Dunnett, 1964) lower than 0.001 in its validation 
with Carlson's TSI using 2017 data (Table 4). This shows the suitability of this index for this type of aquatic reservoir, so that, based on the results previously mentioned that have been evidenced in this work, it is possible to validate the regulatory use of this index for obtaining the trophic status of reservoirs in the various reports monitoring water quality that the Ebro Basin Authority has been consistently conducting. It would also be of interest to validate the methodology and results in other river basins, as well as to apply it to other lagoon ecosystems.

Finally, a linear correlation has been made between the values obtained in the application of the WZI and ZRTI indices in all the reservoirs studied, showing a significant correlation between the two indices with an $\mathrm{r}$ coefficient of 0.865 and Pearson's $r$ critical value below 0.001 (Dunnett, 1964). Given these results and that the WZI index was designed for lakes and the ZRTI index for reservoirs, the ZRTI should be studied for possibilities of application in lakes and beyond to expand its use.

In addition, based on the results of this study, it is recommended that the Rcla and Rzoo-chla indices be revised to ensure that they function correctly in determining ecological potential outside the regions for which they were designed and that the WZI index be corrected to accurately determine the ecological potential of the reservoirs of the Ebro River Basin, though it is recommended that the new ZRTI index be used for this purpose because it is the most efficient index in this context.

\section{ACKNOWLEDGEMENTS}

We are grateful to the Confederación Hidrográfica del Ebro (Ebro Basin Authority - Ministry of Agriculture, Food and Environment of the Government of Spain) for the support provided to the continuous sampling campaigns from 2009 to the present day, without which it would have been impossible to obtain the data necessary for this study.

\section{REFERENCES}

APHA 1998. Standard Methods for the Examination of Water and Wastewater. American
Public Health Association.

AZEVEDO, D. J. S., J. E. L. BARBOSA, W. I. A. GOMES, D. E. PORTO, J. C. MARQUES \& J. MOLOZZI. 2015. Diversity measures in macroinvertebrate and zooplankton communities related to the trophic status of subtropical reservoirs: Contradictory or complementary responses? Ecological Indicators, 50: 135-149. DOI: 10.1016/j.ecolind.2014.10.010 BAYS, J. S. \& T. L. CRISMAN. 1983. Zooplankton and trophic state relationships in Florida lakes. Canadian Journal of Fisheries and Aquatic Sciences, 40: 1813-1819.

BENGRAÏNE, K. \& T. F. MARHABA. 2003. Using principal component analysis to monitor spatial and temporal changes in water quality. Journal of Hazardous Materials, 100: 179-195. DOI: 10.1016/S0304-3894(03) 00104-3

BENZIE, J. A. H. 2005. Cladocera: The genus Daphnia (including Daphniopsis). Guide to the identification of the microinvertebrates of the continental waters of the world. Leiden, The Netherlands: Backhuys Publishers.

BLANCHER, E. C. 1984. Zooplankton-trophic state relationships in some north and central Florida lakes. Hydrobiologia, 109: 251-263.

BURNS, N. M., J. C. RUTHERFORD \& J. S. CLAYTON. 1999. A monitoring and classification system for New Zealand lakes and reservoirs. Lake and Reservoir Management, 15: 255-271. DOI: 10.1080/07438149909354122

CARAMUJO, M. J. \& M. J. BOAVIDA. 2000. The crustacean communities of river Tagus reservoirs: Zooplankton structure as reservoir trophic state indicator. Limnetica, 18: 37-56

CARLSON, R. E. 1977. A trophic state index for lakes. Limnology and Oceanography, 22: 361-369.

CHE 2009. Informe de seguimiento de masas de agua de la cuenca del Ebro. Confederación Hidrográfica del Ebro

DUNNET, C. W. 1964. New tables for multiple comparisons with a control. Biometrics, 20: 482-491. DOI: $10.2307 / 2528490$

EC 2000. Directive 2000/60/EC of the European Parliament and of the Council of 23 October 2000 establishing a framework for community action in the field of water policy. Official 
Journal of the European Communities.

EJSMONT-KARABIN, J. 2012. The usefulness of zooplankton as lake ecosystem indicators: Rotifer trophic state index. Polish Journal of Ecology, 60: 339-350.

GANNON, J. E. \& R. S. STEMBERGER. 1978. Zooplankton (especially crustaceans and rotifers) as indicators of water quality. Transactions of the American Microscopical Society, 97: 16-35.

GARCÍA-CHICOTE, J., C. ROJO \& X. ARMENGOL. 2017. Zooplankton community as tested indicator of trophic state in reservoirs from semiarid Mediterranean river basins. Proceedings of the Conference on Ecological Quality and Conservation Status of Inland Waters. September 28-29, 2017. Pamplona, Spain.

GILBERT, J. D., I. DE VICENTE, F. ORTEGA, E. GARCÍA MUÑOZ, R. JIMÉNEZ-MELERO, G. PARRA \& F. GUERRERO. 2017. Linking watershed land uses and crustacean assemblages in Mediterranean wetlands. Hydrobiologia, 799: 181-191. DOI: 10.1007/ s10750-017-3211-6

GULATI, R. D. 1983. Zooplankton and its grazing as indicators of trophic status in Dutch lakes. Environmental Monitoring and Assessment, 3: 343-354.

HABERMAN, J. \& M. HALDNA. 2014. Indices of zooplankton community as valuable tools in assessing the trophic state and water quality of eutrophic lakes: Long term study of Lake Võrtsjärv. Journal of Limnology, 73(2): 263-273 DOI: 10.4081/jlimnol.2014.828

HAMMER, Ø., D. A. T. HARPER \& P. D. RYAN. 2001. PAST: Paleontological statistics software package for education and data analysis. Palaeontologia Electronica, 4: 9.

LOUGHEED, V. L. \& P. CHOW-FRASER. 2002. Development and use of a zooplankton index of wetland quality in the Laurentian Great Lakes basin. Ecological Applications, 12: 474-486. DOI: $10.2307 / 3060956$

MELLADO, A., E. VICENTE, S. MORATA, X. SORIA, C. PINTOR, C. DURAN, F. FARIÑO \& M. R. MIRACLE. 2010. Phytoplankton communities in reservoirs of the Ebro river basin as ecological status indica- tors. XV Congreso de la Asociación Ibérica de Limnología, Ponta Delgada, Portugal. Book of Abstracts.

MOSS, B., D. STEPHEN, C. ALVAREZ, E. BECARES, W. VAN DE BUND, S. E. COLLINGS, E. VAN DONK, E. DE EYTO, T. FELDMANN, C. FERNÁNDEZ-ALÁEZ, M. FERNÁNDEZALÁEZ, R. J. M. FRANKEN, F. GARCÍA- CRIADO, E. M. GROSS, M. GYLLSTROM, L. A. HANSSON, K. IRVINE, A. JÄRVALT, J. P. JENSEN, E. JEPPESEN, T. KAIRESALO, R. KORNIJÓW, T. KRAUSE, H. KÜ NNAP, A. LAAS, E. LILL, B. LORENS, H. LUUP, M. R. MIRACLE, P. NOGES, T. NOGES, M. NYKÄNEN, I. OTT, W. PECZULA, E. PEETERS, G. PHILLIS, S. ROMO, V. RUSSELL, J. SALUJOE, M. SCHEFFER, K. SIEWERTSEN, H. SMAL, C. TESCH, H. TIMM, L. TUVIKENE, I. TONNO, T. VIRRO, E. VICENTE \& D. WILSON. 2003. The determination of ecological status in shallow lakesa tested system (ECOFRAME) for implementation of the European Water Framework Directive. Aquatic Conservation: Marine and Freshwater Ecosystems, 13: 507-549. DOI: 10.1002/aqc.592

NOGRADY, T., R. POURRIO. \& H. SEGERS. 1995. Rotifera 3. Notommatidae and Scaridiidae. Guides to the Identification of the Microinvertebrates of the Continental Waters of the World 8. (H. Dumont, T. Nogrady, eds.). SPB Academic Publishing BV.

NOGRADY, T. \& H. SEGERS. 2002. Rotifera 6: Asplanchnidae, Gastropodidae, Linfiidae, Microcodidae, Synchaetidae, Trochosphaeridae and Filinia. Guides to the Identification of the Microinvertebrates of the Continental Waters of the World. (H. Dumont, T. Nogrady, eds.). SPB Academic Publishing BV.

OCHOCKA, A. \& A. PASZTALENIEC. 2016. Sensitivity of plankton indices to lake trophicconditions. Environmental Monitoring and Assessment, 188(11): 622. DOI: 10.1007/s10661-016-5634-3

PINTO-COELHO, R., B. PINEL-ALLOUL, G. MÉTHOT \& K. E. HAVENS. 2005. Crustacean zooplankton in lakes and reservoirs of temperate and tropical regions: Variation with 
trophic status. Canadian Journal of Fisheries and Aquatic Sciences, 62: 348-361.

SAHUQUILLO, M., \& M. R. MIRACLE. 2010. Crustacean and rotifer seasonality in a Mediterranean temporary pond with high biodiversity (Lavajo de Abajo de Sinarcas, Eastern Spain). Limnetica, 29: 75-92.

SEGERS, H. 1995. Rotifera 2. The Lecanidae (Monogononta). Guides to the Identification of the Microinvertebrates of the Continental Waters of the World 6. (HJ Dumont, T. Nogrady, eds.). SPB Academic Publishing BV.

SORIA PERPIÑÁ, J. 2017. Noves tecnologies per a la determinació de la qualitat ecologica de l'aigua en embassaments. Ph. D. Thesis. University of Valencia, Spain.

STELLA, E. 1984. Fauna d'Italia. Vol XXI. Crustacea. Copepoda: Calanoida (d'acqua dolce). Edizioni Calderini Bologna.
TER BRAAK, C. J. \& P. F. VERDONSHOT. 1995. Canonical correspondence analysis and related multivariate methods in aquatic ecology. Aquatic Sciences, 57: 255-289.

VERDOW, H., C. J. A. VANECHTED \& E. M. J. DEKKERS. 1978. Ammonium determination based on indophenol with sodium salicylate. Water Research, 12: 399-402.

VICENTE, E. \& M. R. MIRACLE. 1992. The coastal lagoon Albufera de Valencia: An ecosystem under stress. Limnetica, 8: 87-100.

VICENTE, E., C. HOYOS, P. SANCHEZ \& J. CAMBRA. 2005. Protocolo de muestreo y análisis para fitoplancton. Ministerio de Agricultura, Alimentación y Medio Ambiente. Available online (2018-02-11): http://www.mapama.gob.es.

WETZEL, R. G., \& G. E. LIKENS. 2000. Limnological analysis. WB Saunders Co., Philadelphia.

Con el apoyo de:

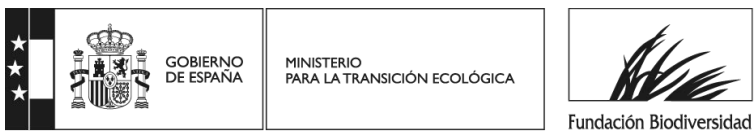

